\title{
The Contested Council: Conflict Dimensions of an Intergovernmental EU Institution
}

\author{
Christina Zimmer, Gerald Schneider and Michael Dobbins \\ University of Konstanz
}

\begin{abstract}
Recent research has tried to uncover the political space in which the Council of Ministers of the European Union decides. Rather than the left-right conflict or a cleavage between governments with national and supranational attitudes, this article shows that a redistributive dimension, decisively shapes the interactions in this most important legislative body of the European Union. In contrast to extant studies, we employ ex ante rather than ex post preference data and rely on correspondence analysis as a means to identify the underlying dimensions of contestation. The article concludes with an empirical investigation of how enlargement will affect the emerging political space within the European Union. Our quantitative analysis suggests that the gulf between net-contributors and net-receivers will further deepen.
\end{abstract}

Many experts have contended that coalition building in the Council of Ministers of the European Union is unpredictable and time-consuming (Peters and Wright, 2001, p. 160). According to this adage, member states do not build permanent alliances, but common interests on individual issues bind them together (Nugent, 1999, p. 474). The secrecy surrounding the negotiations, decisions and protocols has prevented the public from establishing whether this interpretation of casual coalition building is accurate (see Hayes-Renshaw and Wallace, 1997). The lack of reliable data has made it nearly impossible to study the preference and coalition structure within this core intergovernmental body of the European Union.

The data set 'Decision-Making in the European Union' (DEU) (Thomson et al., forthcoming) enables us to identify the negotiation positions of the member states and the conflict structure within the Council. This article makes use of this unique resource and attempts to reduce the conflict space to a few dimensions that reveal the most important cleavages. Our results largely confirm the findings of Mattila and Lane (2001), Mattila (2004) and Thomson et al. (2004) who have pinpointed the north-south dimension as the main line of contestation within the European Union. However, we qualify these results and offer some substantial and methodological innovations to the emerging literature on the European political space (Marks and Steenbergen, 2004). First, although some conflict dimensions that we identified cannot be interpreted that easily, some recurrent patterns of contestation do exist in the intergovernmental council. Our calculations reveal more structure in the interactions of the member states than the similar recent inquiries by Selck (2004) and Thomson et al. (2004) did. Second, our results suggest that the north-south division encompasses various sub-dimensions, the most important of which being the conflict between net-receivers and net-contributors to the EU 
budget. Although the left-right dimension also explains the alignments of governments to a certain degree, the 'utilitarian' dimension, which we identify in this analysis, shapes the conflict structure in the Council more decisively. This result considerably differs from the roll call data analysis by Mattila (2004). He uncovers, in line with studies on the European Parliament (for example Noury 2002), a political space in which the divisions between left and right and between independence and integration-supporting governments are the main dimensions of contestation. Third, we are able to compare the conflict structure within the Council before and after enlargement. We suspect that redistributive conflicts will become more virulent and that the EU will become more producer-friendly and protectionist in the near future (Dobbins et al., 2004). Fourthly, our results are founded upon the analytical technique of correspondence analysis. Although this method has been previously used in the attempt to uncover the conflict structure within the European Parliament (Kreppel and Tsebelis, 1999; Kreppel, 2002), it has not been employed for the analysis of Council interactions. Correspondence analysis also provides accurate results even in the event that the number of cases is relatively small and the preference data are quasi-ordinal, as is the case in our inquiry.

This article is structured as follows: We will first discuss the most recent studies dealing with the political space (or spaces) of the European Union. Our classification of the empirical literature follows the theoretical deductions on the relevant conflict dimensions of the most important EU actors. We use this framework to build a number of hypotheses to be tested after the presentation of the DEU data set and research design. We conclude by comparing the past with the present conflict structure of the enlarged European Union.

\section{Competing Models of Political Contestation within the European Union}

No conclusive evidence has yet been found for the conjecture that five decades of European integration have led to a unifying political space. The existing literature offers three competing models to classify and describe the European political space (Marks and Steenbergen, 2002; 2004). The International Relations Model assumes that European actors disagree along a more or less integration dimension. This assumption can be traced back to realist contributions to the theory of European integration (Hoffmann, 1966) and Moravcsik's (1998) version of intergovernmentalism. This emphasis on the division between supranationalists and nationalists in the EU can also be found in neo-functionalist writings (Haas, 1958) as well as some of the first spatial models developed to study the legislative process of the organisation (for example Tsebelis and Garrett, 1996). These cleavages thus do not coincide with the conflicts surrounding the left-right dimension in domestic policy debates, nor do they acknowledge the extent of social and economic regulation, for which the EU has been increasingly granted extensive authority (Majone 1996).

The Hix/Lord-Model (Hix and Lord, 1997; Hix 1999a; 1999b) conversely suggests that there are two independent conflict dimensions, the left-right and the more versus less integration dimension, which can allegedly be placed orthogonally upon each other. This configuration is based on crosscutting coalitions of interests between functional and territorial groups. The regulation model, on the other 
hand, anticipates conflicts over the extent to which the state should regulate the European economy.

By and large, the empirical studies on the structure of contestation within the European Union can, be attributed to these models. Yet, the overall conclusion that one can gain from these examinations is that no unifying political space within the European Union exists. It seems as if the dimensionality depends by and large on the ingenuity of the political actors and the level at which they become active (Marks and Steenbergen, 2002, p. 888). To start with, strong empirical evidence by independent researchers bolsters the claim that the Members of the European Parliament can largely be classified along the left-right continuum (Attiná, 1990; Noury, 2002; Kreppel and Tsebelis, 1999; Hix et al., 2003). This one-dimensional conflict dominates not only voting within the EP, but also party competition on European issues at the national level (Gabel and Hix, 2002; Pennings, 2002). As Aspinwall (2002, p. 106) shows, there is a robust relationship between the ideological position of government parties and their preference on European integration 'particularly in cases where there is not some overriding pan-ideological national interest at stake'. Parties that assume a position in the centre advocate free trade and international stability, while right-wing and left-wing parties reject further integration due to fears of losing their national autonomy or welfare state (2002, pp. 86-8).

Other authors detect a direct link between the ideology of parties and their support for European integration only with respect to economic and regulatory issues (Hooghe and Marks, 1999, pp. 76-8). In addition to this, a new politics dimension defined by Hooghe, Marks, and Wilson that comprises issues such as immigration, the environment and democratic transparency has emerged (Hooghe, Wilson and Marks, 2002). As the left-right and the new politics dimension are partly associated with the support for European integration, Hooghe, Marks, and Wilson (2004, p. 140) conclude: 'European politics is domestic politics by other means.'

The large national differences within the European party groups have the consequence that the competition between the parties at the European level is perceived to take place only along one dimension. Conflicts on national and territorial issues exist, in other words, only latently, while the negotiations between parties are reduced to a socio-economic dimension (Hix, 1999b). The integration dimension, however, plays an important role in the negotiations within the European Council and the ratification processes of the intergovernmental treaties such as the Maastricht and Amsterdam Treaties (Hug and König, 2002; Bräuniger et al., 2001). Yet, as governments have the possibility to add less conflictive issues or to take highly contentious issues from the negotiation agenda, the conflict structure is not fixed in this intergovernmental arena. The subtraction of controversial topics during the negotiations eased the way for the Amsterdam Treaty through the ratification process. While governments and voters disagreed on this treaty only on one dimension in the end, the Maastricht treaty contained EMU and political union as the main divisive projects.

Despite severe data problems, several recent articles have attempted to map out the conflict structure in the Council of Ministers. Most of these examinations aim to identify possible coalitions among the member states. Lane and Mattila (1998) 
hint at the national dimension as the most important cleavage and the division between the northern and southern members in the coalition building process. Additionally, large member states vote more frequently against the majority than smaller ones (Mattila and Lane, 2001). ${ }^{1}$ Because formal voting is rare in the Council of Ministers as a consequence of early consensus-building, studies that resort to the results of the final votes do not necessarily mirror the actual conflict structure. Mattila (2004) lists some additional explanations as to why the final votes taken in the Council do not always correspond to the preferences of the member states. Countries that hold the EU Presidency oppose majoritarian decisions less frequently than other member states. The tendency of the larger member states to dissent also reflects the inclination of smaller member states to behave strategically and go with the majority against their own preferences.

The analyses of the voting protocols find some support in the interview-based studies that disentangle the patterns of communication within the Council. The nationality of the delegates remains the best explanatory factor for the coalition patterns; the difference between north and south is also crucial (Elgström et al., 2001; Beyers and Dierickx, 1998). However, these communication patterns could indeed likely be shaped by a common language and background shared by the national delegations than the actual policy preferences of the member states.

Hence, to explore the dimensions of contestation within the Council, we need to rely on more direct preference measures. Interviews that unravel the bargaining positions of the actors before the final decision is made provide, in our view, more accurate information on actor preferences than roll call analyses or general surveys on the behaviour of a member state. We will make use of such ex ante data in our tests of the three competing hypotheses that we will derive from the literature in the following.

\section{Theoretical Foundations of the Conflict Structure in the Council of Ministers}

According to the Lipset/Rokkan model of political cleavages (Lipset and Rokkan, 1967, pp. 14f.), the modern party systems of Europe are moulded by historical conflicts involving the foundations of the state, as well as religion and social classes, from which stable social identities and institutions developed. Thus, national political competition is carried out for the most part today along the left-right dimension (Hix and Lord, 1997, p. 25). This ideological dimension reconciles economic and socio-political issues such as regulation, redistribution, employment, individual freedom, religion and ecology (Hix, 1999b, p. 73). However, these historically anchored political alignments restrict the means for political parties to react to the emergence of new issues, as both issue-related orientations that have evolved over a long period of time as well as the allegiance to a certain clientele of voters entail high sunk costs (Marks and Wilson, 2000, pp. 434-6). Thus for political parties and actors there is an incentive to interpret new issues within the framework of already existing cleavages and incorporate them into the given lines of party competition. This, in turn, compels organisations that are active in national policy making to 're-interpret' issues involving European integration along the left-right ideological dimension. 
The rational choice approach argues, on the other hand, that multi-dimensional decision-making entails an enormous increase in transaction costs. As stable results are only possible in one- or two-dimensional spaces (Hinich and Munger, 1997), it is in the interest of all actors participating in the negotiations to limit the dimensionality of the conflict space. If party affiliation and identification are an equally decisive factor for the formation of the preferences of actors in the Council of Ministers, then conflicts should be structured by a left-right dimension within this legislative body.

H1: The conflict structure in the Council of Ministers is founded upon an ideological dimension, along which the member states can be aligned according to the leftright position of their governments.

However, the members of the Council of Ministers are also representatives of their governments and can still be perceived as the greatest advocates of the interests of their nation-states on the EU level. For this reason, conflicts involving matters of national sovereignty and interests tend to emerge much more frequently in the Council of Ministers than between the EP representatives who are grouped along supranational party lines. This is reflected by the initial one-dimensional theoretical studies on decision-making in the EU (for example Tsebelis and Garrett, 1996), according to which the Council, Commission and the EP held different views on the extent of integration. In the stricter sense, the more or less-integration dimension would thus span from the further delegation of competences and the harmonisation of regulatory measures on the European level on to the preservation of national sovereignty.

H2: The conflict structure in the Council of Ministers is based on an integration dimension, along which pro-integration governments can be distinguished from less integrationist governments.

By comparison, Hix (1999b, p. 72f.) defines the 'integration dimension' in general as a national/territorial cleavage in the Council. This division determines conflicts involving state and territorial borders, historical myths, cultures, rights and commitments as well as economic interests (Smith, 1991, p. 14, quoted in Hix, 1999b). The conflicts emerge when national identity or national interests are endangered by integration or when one or several member states seem to be profiting at the costs of others (Hix, 1999b, p. 73).

The agricultural and structural funds of the EU illustrate a particularly striking and blatant form of redistribution and thus the perceived unequal treatment of member states. Viewed within a political-exchange model, the poorer states receive a large part of the redistributive transfer payments as compensation for their approval of certain policies (for example economic integration) on the EU level (Carrubba, 1997). ${ }^{2}$ To a certain extent, the wealthy member states are willing to buy off the consent of the poorer nations by means of subsidies. However, since they finance the redistributive programs alone, while the other member states profit from them or at least offer a smaller contribution, it is in the interest of the net-contributors to keep the expenses for subsidies at the lowest possible level. This constellation of interests characterises not only economic matters, but also social and environmental policy (Hosli, 1996, p. 260). 
H3: The conflict structure in the Council of Ministers is based on a North/Southdimension that best reflects conflicts of interest between net-contributors and netbeneficiaries of subsidies and redistributive policies.

Our following empirical analysis shall now demonstrate which of the discussed conflict lines dominates the struggles in the Council. Is the structure of negotiations marked by the polarisation of left-right interests along party lines? Or are national political or economic interests of greater significance?

\section{Research Design}

National delegations participating in the negotiations and decision-making process in the Council will be regarded as unitary actors. For most Commission proposals (70 percent), an agreement is reached in advance among the working groups or the COREPER (15 to 20 percent) (Hayes-Renshaw and Wallace, 1997, p. 40). However, as the ministers themselves are still able to open up a debate on all contested matters (1997, p. 81), we must assume that national positions are agreed on or that the preferences of the government are anticipated within the working groups and the COREPER.

The centrepiece of the analysis of our research question is the DEU data set (Decision-Making in the European Union). ${ }^{3}$ The DEU data set was developed by an international team of researchers from the Universities of Groningen, Konstanz, Leiden, Ann Arbor (Michigan), Nijmegen and Turku on the basis of the results of quantitative expert interviews. A total of 125 experts, most of whom belonged to the national delegations (Council of Ministers) in Brussels, were consulted. To figure out the preferences of the new member states, we also conducted our own interviews with Commission officials, members of the European Parliament and interest groups in Brussels.

The DEU data set contains the preferences of the decisive institutional actors in the legislative process: the ideal points of the 15 member states, the European Commission and the EP on 174 issues from 70 Commission proposals on decrees, directives and decisions. We only measured the negotiation preferences of the actors, that is their preferred policy positions after the proposal was submitted, but also before the adoption of a common position on the part of the Council of Ministers. ${ }^{4}$ We agree with Bueno de Mesquita (2004) that the data we obtained reflect sincere negotiation stances rather than the 'true' ideal point of a member state that cannot be deduced from expert interviews. The ideal point estimates of the member states were standardised on a scale from 0 to $100 . .^{5}$ The nature of the issues varies considerably. While some issues stand for the qualitative choice between two or more options, most other scales are quasi-ordinal, rather than nominal.

The data are restricted to the decisional procedures Consultation and Co-decision. Of the 70 proposals, 42 were governed by the Consultation procedure, while 28 entailed the participation of the Parliament as a co-decision-maker. As for the selection of issues, there was no limitation to certain policy areas, with the most frequent being common market and agricultural issues. The selection of cases is restricted to a timeframe between January 1999 and December 2000, while the largest part of the proposals was presided over between May 1999 and February 
2002. By doing so, we aimed to ensure that the consulted experts were available and could still remember the Commission proposals well. A further motive was to prevent the interviewees from deriving their preference estimates from their actual voting behaviour, which would have led to ex post distortions.

Missing scores in the analysis were replaced by the mean score between the reference point and the position of the Commission. Thus, those member states that could not be attributed a preference score in the expert interviews were given a neutral position. Issues for which the preference positions are unknown for more than four member states were discarded from the analysis (see Selck and Steunenberg, 2004, p. 14).

Factor analyses (FA) on the basis of multidimensional scaling are frequently employed tools to examine the latent conflict structure of multiple variables. Selck (2004) relies on factor-analytical techniques to uncover the dimensions of contestation in the Council, while Mattila and Lane (2001) and Thomson et al. (2004) use multidimensional scaling. Factor analysis serves to reduce a multitude of variables to a few hypothetical constructs (factors), which represent linear combinations of the observed variables (Kim and Mueller, 1978). However, for the analysis of the DEU data set, a FA has several disadvantages. For example, the data are to be measured on an interval scale level, because the FA is based on correlation matrixes and weighted variable sums. ${ }^{6}$ Furthermore, the sample size of the DEU data set can be regarded as too small for a FA. Multidimensional scaling (MDS) in return is mainly a graphical device that allows a researcher to detect the spatial ordering of objects, in our case: countries, in a one- or two-dimensional space. The technique does, however, not enable us to trace the positions back to the influence of the issues under contestation.

The drawbacks of FA and MDS can be avoided with an alternative technique. Correspondence Analysis (CA), which is frequently labelled as a 'Principle Components Analysis with Categorical Data' (Benzécri et al., 1973; Greenacre, 1984), describes, like the FA, the latent characteristics of manifested variables (Blasius, 2001, p. 83). A CA traces the latent structure of nominally or ordinally scaled data. It is especially suitable for analyses with a small number of cases (Blasius, 2001, p. 330). In a CA the row or column profiles of a frequency table are calculated in order to compare their similarity with the average profile of the rows and columns. ${ }^{7}$ For the DEU, the deviations (Chi-Square-Distances) between the row scores of MS $\mathrm{j}$ and the row scores of the average MS are determined according to (1):

$$
\begin{aligned}
& \chi^{2}=\sum_{j}\left(\left(\operatorname{obs}_{\mathrm{ij}}-\exp _{\mathrm{ij}}\right)^{2} / \exp _{\mathrm{ij}}\right) \text { where } \\
& \operatorname{obs}_{\mathrm{ij}}=\text { observed score of member state } \mathrm{i} \text { on issue } \mathrm{j} \\
& \exp _{\mathrm{ij}}=\text { expected score of member state } \mathrm{i} \text { on issue } \mathrm{j}
\end{aligned}
$$

We have also used the DEU data set and the secondary literature to develop preference profiles for the most important policy fields in which the Council of Ministers is a co-legislator. Against this background, we conducted 16 structured interviews with representatives of the accession countries and Commission representatives dealing with enlargement. We asked the experts to identify the preferences of the new member states along the preference continua with the old member states. ${ }^{8}$ 
Figure 1: Object Points of the Member States, 3-D Model
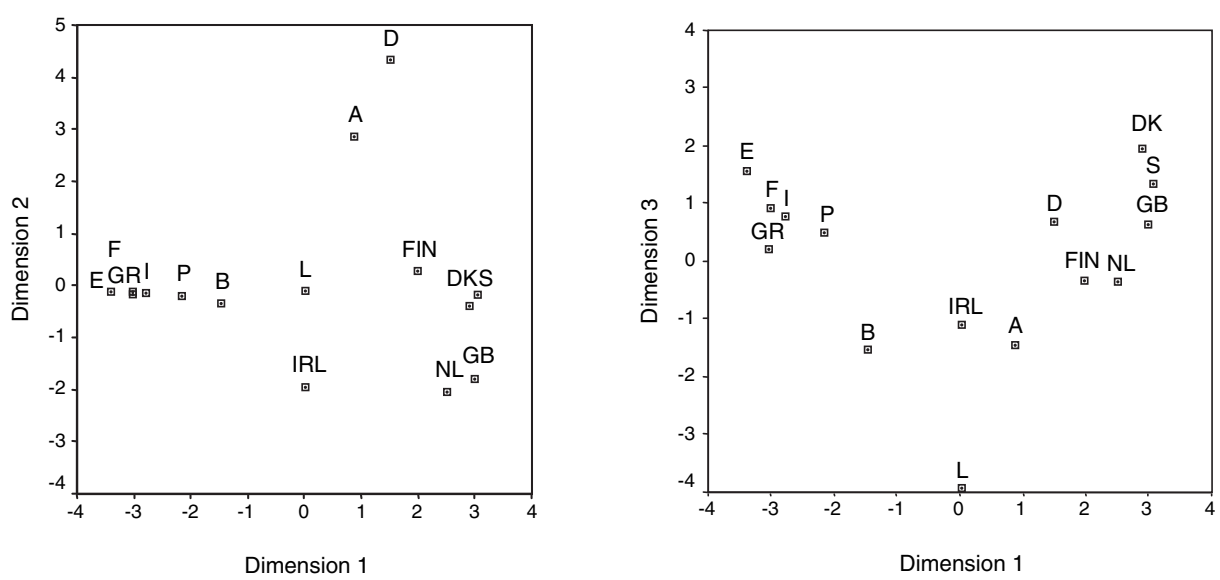

\section{Results: Conflict Dimensions in the Council of Ministers}

Figure 1 depicts the alignment of the preference profiles of the member states in a three-dimensional model on the basis of an analysis of the entire data set. Along the first dimension, the southern states can be clearly distinguished from the northern member states; Ireland and Luxembourg assume a position in the middle. The second division demonstrates the widest gap between Great Britain, the Netherlands and Ireland in the lower area and Germany (and to a lesser extent Austria) in the upper part of the illustration. Along the third dimension, Luxembourg is isolated from the other member states, while Austria, Ireland and Belgium assume positions in the middle.

In a CA the interpretation of the policy content of the dimensions is founded upon the columns (issues) with extreme component loadings (that is coordinates of the variables in the object space). Since the Council of Ministers predominantly presides over very detailed topics, the content of the dimensions is also greatly dependent on the specific issues at hand, making it difficult to draw final conclusions on the general conflict structure within the Council.

The results listed in Table 1 provide nevertheless a solid framework for the interpretation of the underlying policy-content. Analyses of the data using principal components analysis, a factor analytic technique, or multidimensional scaling show similar results to those of the CA. ${ }^{9}$ The distinction between interval and ordinalscaled data evidently does not lead to any notable differences in the analysis of the DEU. Tests of internal stability (Greenacre, 1993, pp. 171-7) confirm the results. If we were to leave out the preference scores of Germany, an outlier on the second dimension, it turns out that the conflict potential with Germany 'covers up' differences in the preference profiles of the remaining member states.

The first dimension is dominated by the regulation of the common market as well as subsidies for agriculture, culture and external financial support. The alignment 
Table 1: Possible Interpretations of the Dimensions in DEU

\begin{tabular}{|l|l|l|l|l|l|}
\hline & & D2 & $\begin{array}{l}\text { Explained } \\
\text { variation, } \\
2 D \text {-model }\end{array}$ & D3 & $\begin{array}{c}\text { Explained } \\
\text { variation, } \\
3 D \text {-model }\end{array}$ \\
\hline DEU & $\begin{array}{l}\text { market } \\
\text { regulation, } \\
\text { subsidies }\end{array}$ & $\begin{array}{l}\text { consumer } \\
\text { protection, } \\
\text { subsidies }\end{array}$ & $44.8 \%$ & $\begin{array}{l}\text { subsidies, } \\
\text { economic interests } \\
\text { protectionism }\end{array}$ & $53.7 \%$ \\
\hline
\end{tabular}

of the member states along this axis coincides with the predictions in $H 3 .{ }^{10}$ Spain, Greece, France, Italy and Portugal receive relatively high sums of agricultural and structural funds, ${ }^{11}$ while Great Britain, Germany, Luxembourg, Austria, Sweden and the Netherlands make large contributions. Although the Danes receive high subsidy payments, they are not very willing to increase such expenses. The same also holds for the Finns, who only provide small net-contributions. To explain this peculiarity, scholars have offered an argument based on the 'cultural connectedness ${ }^{\prime 2}$ of certain groups of member states (Beyers and Dierickx, 1998; Elgström et al., 2001). The behaviour of the Finns can also be interpreted in this case as their desire to be 'good Europeans' and to avoid advocating extreme positions. ${ }^{13}$ This argument points to a conflict of interest for the Irish. On the one hand, as receivers of subsidies they are closely attached to the southern states, while on the other hand they are affiliated with the English language and Anglo-Saxon constitutional, legal and state traditions.

As a rule, the results confirm the observation that the poorer southern member states demand more market regulation, protectionism and redistribution than the northern member states, who seek increased free trade, market liberalisation and the restriction of EU expenses (for example Hamilton, 1991, quoted in Hosli, 1996). The North, for example, sought to limit or dismantle subsidy programmes for the production of sugar (n00250il) and oil (n00358il und i2). Conversely, the northern member states tend to advocate stricter regulations for producers, for example fishing restrictions (n96160il) or measures to protect laying hens (n98092). Thus, an unambiguous alignment of the member states along a clearly defined regulation or left-right dimension spanning from greater market regulation to liberal antiprotectionism is a difficult task, ${ }^{14}$ as the actual preference positions of the member states are dependent on specific nation-state interest constellations and conflicts. For example, Denmark and Great Britain are generally regarded as strong advocates of dismantling subsidy programmes in the EU. Denmark, however, proposes an expansion of subsidies for low-fat milk in schools because consumption of such milk is high in Denmark (n99246i2).

The second dimension can be defined primarily as conflicts involving the representation of consumer and producer interests as well as EU subsidies. However, state preferences often tend to be inconsistent in particular when core national interests are at stake. Germany assumes the most isolated position here and is the furthest away from the Netherlands and Great Britain. As in the following 
examples, Germany demands further regulation, more protectionism and subsidies, if these are in accord with its vital national economic and consumer interests: The German delegation supports, for instance, an agreement on the length of trucks to the advantage of German industries (d00060il), advocates the protectionist position in Internet commerce demanded by trade associations (d98325i2), and supports the banning of phthalates in children's toys (d99238) and the continuance of EU-subsidies for milk and dairy products (n99246il).

Diverse bureaucratic traditions and the existing national legislation also appear to be of significance here, for example in reaction to the Commission's proposal to regulate market access for service providers of electronic signatures by means of a system of self-control (d98191). This coincides much more with the system of corporatist self-regulation of the economy that Germany is familiar with than the divergent national traditions in Great Britain and Ireland, for example (see Streeck and Schmitter, 1996, p. 143; Scharpf, 1994, p. 150). This clinging to the existing national legislation also explains the conflicting positions on the manner in which a 'fair' price was set for company takeovers (d9534lil).

The third dimension sheds light on further disparities among the member states. Throughout the entire data set, Luxembourg tends to be in an isolated position, which primarily has to do with its aversion to the harmonisation of taxes. Unsurprisingly, the third dimension also reflects the tension between northern and southern member states.

Thus, for the entire data set, conflicts involving economic liberalisation and regulation of the common market can be distinguished from those involving consumer protection. For the redistributive issues, though, no isolated conflict line could be identified. Controversial matters of subsidy payments and decisions on the EU budget interfere with the conflict structure. The analysis according to policy domains provides clearer results. Table 2 illustrates the explained variation and also

Table 2: Results by Policy Area

\begin{tabular}{|c|c|c|c|c|}
\hline & \multicolumn{2}{|c|}{$\begin{array}{c}\text { Explained } \\
\text { variation in \% }\end{array}$} & \multicolumn{2}{|c|}{ Interpretation of the dimensions } \\
\hline & 2D-model & 3D-model & D1 & $D 2$ \\
\hline $\begin{array}{l}\text { Common } \\
\text { market }\end{array}$ & 64.0 & 76.5 & Market regulation & $\begin{array}{l}\text { Consumer } \\
\text { protection }\end{array}$ \\
\hline Agriculture & 62.1 & 70.7 & Agricultural subsidies & Agricultural subsidies \\
\hline Fisheries & 67.0 & 79.2 & Economic interests & National sovereignty \\
\hline $\begin{array}{l}\text { Justice and } \\
\text { Home Affairs }\end{array}$ & 48.5 & 66.9 & $\begin{array}{l}\text { Financial assistance } \\
\text { and services }\end{array}$ & National sovereignty \\
\hline $\begin{array}{l}\text { Economics } \\
\text { and } \\
\text { Finance }\end{array}$ & 75.6 & 86.7 & $\begin{array}{l}\text { Harmonisation of } \\
\text { taxes }\end{array}$ & Financial interests \\
\hline
\end{tabular}


offers an interpretation of the first two dimensions in terms of underlying policy content. ${ }^{15}$

In the Common Market Council the conflicts are structured by the diverse preferences of the member states for protectionist or free trade policies ${ }^{16}$ and consumer protection. ${ }^{17}$ Proceedings in the Council for Agriculture focus nearly exclusively on agricultural subsidies. As for the second dimension, it is evident that Austria, Germany, Finland and the Netherlands also support certain subsidies because they profit from the existing price systems. ${ }^{18}$ Great Britain, Denmark and Sweden, on the other hand, are characterised by their aversion to further increases in subsidies, even though some of their national economic sectors often do benefit from current schemes.

From an overall perspective, we have identified a relatively stable conflict line within the Council of Ministers, namely the conflict between the north and south, around which opposed voting blocks emerge over matters of subsides and financial contributions, market regulation and protectionism. Contrary to Thomson et al. (2004) who forecast an overall lack of structure in the positions of the legislative actors, we were able to associate actors' preferences and the resulting coalitions with specific financial, economic and protectionist interests, the influence of national interest groups and national administrative or legal traditions. ${ }^{19}$

To put our claims onto a more solid footing, we have conducted bivariate tests. Table 3 depicts the correlation between the independent variables and the ranking that the countries obtained on the different dimensions that we identified with the help of CA. We use the Manifesto data by Budge et al. (2001) to measure the positions the member state governments on the left-right and the integration/anti-integration scale. To measure government support for the EU, we additionally used Ray (1999). Data assembled by Rodden (2002) was employed to determine the extent to which a country was among the net-contributors or net-beneficiaries of the EU's agrarian and structural (cohesion) funds between 1995 and 1999.

Table 3: Bivariate Relationships Between Independent Variables and the Position of a Country on the Conflict Dimensions

\begin{tabular}{llllll} 
& \multicolumn{3}{c}{ Dimension 1 } & \multicolumn{3}{c}{ Dimension 2 } \\
\hline Government left-right orientation & 0.42 & $(0.12)$ & -0.24 & $(0.39)$ \\
Government EU support (Budge) & 0.20 & $(0.46)$ & -0.25 & $(0.37)$ \\
Government EU support (Ray) & 0.06 & $(0.81)$ & 0.05 & $(0.85)$ \\
Net transfers as a share of GDP & 0.54 & $(0.04)$ & 0.18 & $(0.52)$ \\
Agricultural transfers as share of GDP & 0.37 & $(0.18)$ & 0.06 & $(0.83)$ \\
Structural fund transfers as a share GDP & 0.67 & $(0.007)$ & -0.11 & $(0.70)$
\end{tabular}

Note: The entries are Spearman rank order correlation coefficients; level of significance in parentheses. The number of cases for all coefficients is 15 . 
The bivariate tests of the three competing hypotheses clearly show that the conflict over the EU transfer payments exerts the only systematic influence on the interactions in the Council of Ministers. The status of a member state as a netcontributor or net-beneficiary is thus crucial for our understanding of the intergovernmental negotiations in the European Union. In the EU of 15 member states, the redistributive conflict largely coincided with the geographical north-south division of the countries. We will explore below how the eastern enlargement will influence this pattern of contestation. Note that the results are similar for dimensions of conflict that we obtained through other estimation techniques (principal component analysis, multidimensional scaling). Furthermore, the results also remain robust if we move to multivariate models.

The bivariate tests lead to a clear rejection of the international relations model as a convincing interpretation of the conflicts within the Council of Ministers. While the conflict over the depth of integration within the European Union often explains the negotiations within the European Council, it fails to do so for the other intergovernmental body of the organisation. The preferences of the member states and the resulting conflicts thus appear to be more the product of national interests and regulatory traditions than their desire for more or less integration (H2). Note that we do not offer a deterministic explanation of legislative decision making here. Although France and Italy have been net-contributors in the late 1990s and early 2000s, they belong to the subsidy-friendly camp. Denmark, by contrast, which was a net-receiver belongs to the opposing camp. ${ }^{20}$

The results reported in Table 3 finally only lend very weak support to the hypothesis that party lines or ideology determine the preference structure in the Council (H1). This result is in considerable contrast to the roll call analysis by Mattila (2004). According to his analysis, the left-right placement of governments significantly affects the number of times that a national delegate objects to a majoritarian decision. We believe that the discrepancies between our findings largely have to do with varying data sources. As for roll call votes, governments might seem forced to object to a decision by member states with another ideology to please their supporters back home. Their negotiation position might, however, not have been that far away from the stances of the other governments. Although most analyses on the European Parliament also rely on roll call data, they seem to reveal that ideology is a much more important consideration in the legislature than in the Council.

\section{The Consequences of Enlargement}

This section switches gear and briefly addresses whether and how enlargement has an impact on the north-south dimension and its underlying sub-components such as subsidy matters, consumer-friendly regulation and fisheries restrictions. Kerremans (1998) forecasts the emergence of a north/south/east conflict structure, which could serve as a further obstacle to the decision-making process in the Council. However, our empirical analysis of the preferences of the new member states shows that this expectation is unfounded (Dobbins et al., 2004).

Instead of offering nonchalant assumptions on post-enlargement policy making, we opted for a more systematic approach. As the dimensions defined above (north- 
south, +/- integration, left-right) are somewhat too broad to measure the specific policy alignments of the new members, we allocated issues from the DEU data set to specific policy domains (for example agriculture, consumer affairs). As the scales contained more information than the DEU data, we conducted a factor analysis to extract the underlying conflict dimensions according to their factor loadings. After calculating the policy preferences (so-called factor scores) of the EU 15 along these conflict lines on a scale from $0-100,{ }^{21}$ we expanded the scope of the analysis with data from secondary literature on policy positions and conflict lines not documented in the data set. ${ }^{22}$ In total, we constructed preference profiles for six particularly contested conflict lines: (1) abolishment/preservation of agricultural subsidies, (2) consumer-friendly versus producer-friendly regulation, (3) restrictions in fisheries, (4) deregulation versus interventionism in the common market, (5) social policy: labour versus capital, (6) environmental policy: status quo versus more regulation. We then carried out 16 semi-structured interviews with highranking EU experts on enlargement and diplomatic representatives of the new members to pinpoint the aggregate policy positions of the new members along these existing preference continua. ${ }^{23}$

Using the median on the basis of Council voting weights, we analysed to what extent and in which direction the majority position will shift in the Council. By and large, the results confirm the assumption that enlargement exports greater preference heterogeneity to the EU, although the new members are by no means a homogeneous unit in terms of their policy positions. ${ }^{24}$ However, the implications for future policy making are clear: the coalition of subsidy-dependent states will be fortified, the EU is likely to become more producer-friendly and a shift towards more regulation in common market policies is expected. To bolster these claims, we present detailed results for two such policy areas.

Figure 2 offers an illustration of how the conflict structure over subsidies has most likely changed as a consequence of enlargement. The data depict even more pronounced variation among the positions of CEECs than among the EU 15 though with a majority of them falling into the group of subsidy-dependent southern states. The spectrum spans from Poland, with nearly one-third of the population employed in agriculture, to Malta, which is not affected by any of the existing subsidies schemes. Due to the mere size of the agricultural work force in the new member states, the divide between industrial and agricultural economies is bound to be sharpened in future legislative games. In the past, though, more wealthy states have been able to buy the support of the poorer agricultural states by securing them access to cohesion funds (see Allen, 1996; Carubba, 1997). However,

Figure 2: Positions on Agricultural Subsidies

\begin{tabular}{|c|c|c|c|c|c|c|c|c|c|}
\hline M & & $\mathbf{C Z}$ & A D EP & & & EST SLO & LT LV & GR & \\
\hline S DK & GB & NL SK & FIN Com & SQ L & & B IRL & F I CY & H P E & PL \\
\hline 0 & 10 & 20 & 30 & 40 & 50 & 60 & 70 & 80 & 100 \\
\hline
\end{tabular}


Figure 3: The Producer-consumer Divide in the EU-25

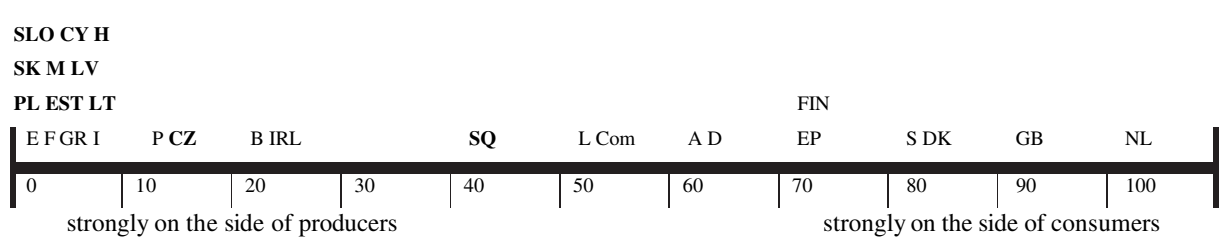

enlargement will inevitably polarise the industrial-agrarian or rich-poor divide, limiting the feasibility of this policy-making mode. The results indicate that tensions between burden and benefit sharing will inexorably complicate Council decision-making.

The north-south dimension also comprises the sub-conflict between consumers and producers, with the north generally advocating consumer-friendly legislation (Young and Wallace, 2000, pp. 8-13). Figure 3 shows the overwhelmingly producer-friendly attitude among the new members, who are likely to align themselves with the southern states.

The reasons for this can be traced back to the painstaking process of adopting the acquis communautaire, which has put the transformation states in a bind. They are required to demonstrate proof of their capacity to 'digest' the strict consumer and environmental legislation in the single market acquis, even though this legislation is costly and arguably detrimental to their economic transformation and industrial development. This burden is compounded by the fact that the new members will most likely not be entitled to the same amount of financial support as the southern states to overcome the disadvantages of increased external competition. In other words, the accession countries are expected to endure immediate costs for potential integration benefits in the long run (Hughes, Sasse and Gordon, 2002, p. 333). By bringing 10 producer-friendly actors on the playing field, enlargement could fundamentally alter the legislative balance between producer and civic interests. Our overall forecast for the legislative impact of enlargement is summed up in Table 4, which illustrates the implications of enlargement for the redistributive dimension we detected for the 'old' EU with 15 member states.

As for the left-right dimension concerning the degree of market regulation, we also arrive at the conclusion that southern states that advocate greater regulation of the common market are set to profit from enlargement. After an unprecedented wave of privatisation and deregulation, centre-left parties demanding a moderate dosage of state economic regulation and trade protection enjoy great popularity in the new member states. The preference for a moderate dosage of regulation is rooted in their desire for a framework of 'selective regulatory alignment' (see Sedelmeier, 2002, p. 640; Young and Wallace, 2000). This would allow the transition economies greater leverage in setting their own economic priorities and policies without being overly exposed to external forces of de-regulation and liberalisation. At least in the 
Table 4: The Predicted Impact of Enlargement on Existing Cleavages in the Council of Ministers

\begin{tabular}{lcll} 
& $\begin{array}{c}\text { Change in } \\
\text { Median Position } \\
\text { (weighted by } \\
\text { Council votes) }\end{array}$ & \multicolumn{1}{c}{$\begin{array}{c}\text { Direction } \\
\text { of Shift }\end{array}$} & $\begin{array}{c}\text { Strengthened } \\
\text { Coalition }\end{array}$ \\
\hline $\begin{array}{l}\text { Policy Domain } \\
\text { Agricultural Subsidies }\end{array}$ & +8.6 & $\begin{array}{l}\text { more subsidies } \\
\text { producers' } \\
\text { interests }\end{array}$ & $\begin{array}{l}\text { south } \\
\text { south }\end{array}$ \\
Producers/Consumers & -20.5 & - & neutral effect \\
Fisheries & 0 & more regulation & south \\
$\begin{array}{l}\text { Interventionist } \\
\text { regulation of the }\end{array}$ & +15.8 & (intervention) & \\
$\quad$ Common Market & & no new standards & south \\
Environmental Policy & -8.3 & employer/capital & south \\
Social Policy Labour & -1.7 & interests & \\
$\quad$ vs. Capital & & & \\
$\quad$ (Unanimity Rule!) & &
\end{tabular}

early years of membership, most new members express a desire for a moderately regulated economy to facilitate structural adjustments and prepare firms for European and international competition. This explains both the aversion to further harmonised consumer legislation as well as full-scale market liberalisation.

As for our central legislative dimension in the Council, the shifts in the weighted median lead us to the tentative conclusion that the southern block will be strengthened by enlargement, as most of the new members fall into the group of subsidydependent states. Furthermore, we predict that producers' and capital interests will be reinforced, with the new members joining the coalition of southern states, who resist further consumer-friendly legislation and trade liberalisation.

\section{Conclusion and Outlook}

The evaluation of quantitative preference data on negotiations on Commission proposals in the Council of Ministers only partially confirms the hypotheses derived from theoretical foundations. We identified a very stable north-south dimension that illustrates the conflicts over the extent of market regulation, protectionism and subsidies. The preferences of the member states greatly depend on their respective status as net-contributors or net-receivers of EU-subsidies. The poorer member states, both from the south and the east, prefer, for the most part, extensive regulation of the market with low production costs, while the northern member states tend to advocate greater competition.

Our examination reveals that enlargement will most likely increase the significance of these dimensions of conflict. The rigid voting stipulations of the Nice Treaty are 
not a remedy to this predicament as they fortify the already existing status quo bias. The extent to which the EU constitution - if it ever comes into force - will remedy the tensions over the distributive question remain to be seen. The increased bargaining complexity and heterogeneity that enlargement entails is regrettably still juxtaposed to an institutional framework that aggravates underlying tensions and promotes gridlock. In light of these forecasts, linking enlargement with internal reform of the EU seems to be a more urgent endeavour than ever, as it may mitigate the negative externalities brought on by the strengthened camp of subsidyhunters, protectionists, and advocates of excessive market regulation.

If diverse issue-specific conflict lines were to run parallel to national interest constellations, it would perhaps alleviate the burden put on the architects of European integration. However, as our analysis has demonstrated for such conflict dimensions, no general interpretation based on policy-content is possible. Classifying the member states according to their overall preference patterns fails due to the inconsistency of the preference profiles. Coinciding preferences can frequently be traced back to common financial, economic or 'cultural' interests, but are by no means consistent. Thus the conflict structure of the Council of Ministers is different than that of the European Parliament. Proceedings in the EP are dominated by the leftright conflict carried out by parties and factions, while in the Council differences between nation-states prevail. Such crosswise conflict lines serve to hinder agreements between the institutions in the European legislative process.

We equally must gain an intuitive grasp of the role of the European Commission in the European conflict space. Future research could tap into the studies on the supranational versus intergovernmental orientations of higher Commission officials (see Hooghe, 1999). The gathering and analysis of preference data would also help us draw conclusions on the predominant cleavages and conflict lines in the Commission. For example, a quantitative empirical analysis might investigate whether the nationality of the Commission officials has an influence at all (Page, 1997, p. 136). This would enhance our knowledge of the supranational or intergovernmental character of the Commission vis-à-vis the conflict structures in the Council of Ministers and the European Parliament.

(Accepted: 18 August 2004)

\begin{abstract}
About the Authors
Christina Zimmer, Department of Politics and Management, University of Konstanz, Box D 86, D-78457 Konstanz, Germany; email: christina.c.zimmer@web.de

Gerald Schneider, Department of Politics and Management, University of Konstanz, Box D 86, D-78457 Konstanz, Germany; email: gerald.schneider@uni-konstanz.de
\end{abstract}

Michael Dobbins, Department of Politics and Management, University of Konstanz, Box D 86, D-78457 Konstanz, Germany; email: Michael.Dobbins@uni-konstanz.de

\title{
Notes
}

A previous version of this paper was presented at the second Pan-European Conference on EU Politics, Bologna, 24-26 June, 2004. We would like to thank three anonymous referees as well as Matt Gabel, Simon Hix, Gary Marks, and Mikko Mattila for their comments. Research support by the German Research Foundation is gratefully acknowledged. 
1 The analysis is based on the yearly Review of the Council's Work or the Monthly Summary of Council Acts in a time-frame between 1994 and 1998, published by the General Secretary of the Council of Ministers of the EU.

2 Carruba and Volden (2001) show along these lines that the choice of an institution can be endogenous.

3 The description of the data is based, for the most part, on Thomson et al. (forthcoming) and Selck (2004, pp. 13-5). For a full description of the research project see Thomson et al. (forthcoming) and the March 2004 issue of European Union Politics.

4 A prerequisite for the selection of the proposals was their 'contestedness'. A proposal had to be mentioned in at least five lines of text in the Bulletin Quotidien, Agence Europe. Thus, the international research team sought to avoid incorporating such Commission proposals that entailed mere technical modifications and did not lead to conflicts between the member states.

5 In the analysis, the value 0 had to be replaced by 1 in all cases, because 0 is an invalid value.

6 However, a factor analysis of ordinal data can be justified pragmatically, because social science variables are primarily regarded as 'continual latent variables with a normal distribution' that can be measured by indicators with minimal measuring errors (Schnell et al., 1999, p. 142). The data we used were originally conceived as interval scales. Yet, the scales that were obtained through expert interviews often only contain a small number of policy positions and can thus be interpreted as quasi-ordinal scales. See also Selck (2004) on the difficulties associated with ordinal-scale preference measures.

7 The calculation is also possible for preference scores. In order to secure the equal weighting of all scores in the analysis, a so-called doubling of the data is carried out (Greenacre, 1993, p. 163). In this procedure every row (positive pole) obtains a row with the complementary preference scores (negative pole, difference between 100 and the preference value).

8 A full description of these interviews can be found at http://www.ub.uni-konstanz.de/kops/volltexte/2003/1021.

9 The first author has analysed the DEU data set with the help of principal component analysis, multidimensional scaling and cluster analysis. The full report on the different scaling techniques can be found at http://www.ub.uni-konstanz.de/kops/volltexte/2003/1111/.

10 The underlying data on the transfer payments between the EU and the member states have been gathered by Rodden (2002).

11 Italy, France, and Belgium are not net-receivers, but only provided a small contribution in terms of the percentage of their GDP from 1995 to 1999. However, they have profited considerably from structural funds both in this timeframe and beyond, particularly in the agrarian sector.

12 Common language, traditions of cooperation, geographical location.

13 Source: Report on DEU, Report on Commission proposal COM (1999) 617/COD 1999/0252.

14 The left-right positions of the governments $(\mathrm{Hl})$ were gathered from the data of the Comparative Manifestos Project (Budge et al., 2001). The index score of a governing party was weighted by the number of its cabinet members. In the case of a change in government, the scores were weighted by the number of months in which a government was in office (see Mattila, 2004).

15 We do not offer an interpretation of a third dimension because of the limitations of the data; the number of issues is too small and their contents too specific.

16 The northern states mostly take a liberal position, while the south is more protectionist.

17 In consumer affairs, Germany, Austria and the Scandinavian states are juxtaposed to Great Britain, Ireland and the Netherlands.

18 The subsidies for beef and calf (n98109i2) and for dairy products (n98110) have the highest component loadings here.

19 This could also be due to the data itself though, as the DEU contains preferences of member states on very specific topics, making an unambiguous conceptualisation along general conflict lines difficult.

20 We would like to thank an anonymous reviewer for pointing out these discrepancies between our findings and the status of these three states as winners and losers of EU transfers.

21 After pinpointing the preferences of the EU-15, the scores were rescaled so that the EU-15 occupy positions between 20-80, leaving room for more extreme preferences among the new members.

22 Preferences for environmental policies: Tsebelis (1994); Holzinger (1997); Bomberg and Peterson (1999); Young and Wallace (2000). For social policy: Social expenditure per capita EU-15 for 2000 (Eurostat). 
23 A detailed description of these interviews and the results can be found in http://www.ub.uni-konstanz.de/kops/volltexte/2003/1021.

24 A great diversity among the accession states can be observed in their positions on fisheries, foreign trade (industrial and agricultural), subsidies and other matters that do not involve increased production costs (see Dobbins et al., 2004).

\section{References}

Allen, D. (1996) 'Cohesion and Structural Adjustment', in H. Wallace and W. Wallace (eds), Policy Making in the European Union. Oxford: Oxford University Press, pp. 209-33.

Aspinwall, M. (2002) 'Preferring Europe. Ideology and National Preferences on European Integration', European Union Politics, 3 (1), 81-111.

Attiná, F. (1990) 'The voting behaviour of the European Parliament members and the problem of the Europarties', European Journal of Political Research, 18 (4), 557-79.

Beyers, J. and Dierickx, G. (1998) 'The Working Groups of the Council of the European Union: Supranational or Intergovernmental Negotiations?', Journal of Common Market Studies, 36 (3), 289-317.

Benzécri, J.-P. et al. (1973) L'analyse des données. L'analyse des correspondances. Dunod: Paris.

Blasius, J. (2001) Korrespondenzanalyse. München: Oldenbourg.

Bomberg, Elizabeth and Peterson, John (1999) Decision Making in the European Union. New York: Palgrave.

Bräuninger, T., Cornelius, T., König, T. and Schuster, T. (2001) 'The dynamics of European integration: a constitutional analysis of the Amsterdam Treaty' in G. Schneider and M. Aspinwall (eds), The Rules of Integration. Institutionalist approaches to the study of Europe. Manchester: Manchester University Press, pp. 46-68.

Budge, I., Klingemann, H.-D., Volkens, A., Bara, J. and Tanenbaum, E. (2001) Mapping Policy Preferences: Parties, Electors, and Governments, 1945-1998. Oxford: Oxford University Press.

Bueno de Mesquita, B. (2004) 'Decision Making Models, Rigor and New Puzzles', European Union Politics, 5 (1), 125-38.

Carubba, C. J. (1997) 'Net Financial Transfers in the European Union: Who Gets What and Why?', Journal of Politics, 59 (2), 469-96.

Carruba, C. J. and Volden, C. (2001) 'Explaining Institutional Change in the European Union', European Union Politics, 2 (1), 5-30.

Dobbins, M., Drüner, D. and Schneider, G. (2004) 'Kopenhagener Konsequenzen: Gesetzgebung in der EU vor und nach der Erweiterung', Zeitschrift für Parlamentsfragen, 35 (1), 51-67.

Elgström, O., Bjurulf, B., Johansson, J. and Sannerstedt, A. (2001) 'Coalitions in European Union Negotiations', Scandinavian Political Studies, 24 (2), 111-28.

Gabel, M. and Hix, S. (2002) 'Defining the EU Political Space. An Empirical Study of the European Elections Manifestos, 1979-1999', Comparative Political Studies, 35 (8), 934-64.

Greenacre, M. J. (1984) Theory and Applications of Correspondence Analysis. London: Academic Press.

Greenacre, M. J. (1993) Correspondence Analysis in Practice. London: Academic Press.

Hamilton, C. B. (1991) 'The Nordic EFTA Countries' Options: Seeking Community Membership or a Permanent EEA-Accord', Discussion Paper 524. London: Centre for Economic Policy Research.

Haas, E. B. (1958) The Uniting of Europe. Stanford CA: Stanford University Press.

Hayes-Renshaw, F. and Wallace, H. (1997) The Council of Ministers. London: Macmillan.

Hinich, M. J. and Munger, M. C. (1997) Analytical Politics. Cambridge: Cambridge University Press.

Hix, S. (1999a) The Political System of the European Union. London: Macmillan.

Hix, S. (1999b) 'Dimensions and alignments in European Union politics: Cognitive constraints and partisan responses', European Journal of Political Research, 35 (1), 69-106.

Hix, S. and Lord, C. (1997) Political Parties in the European Union. New York: St. Martin's.

Hix, S., Noury, A. and Roland, G. (2003) 'Politics Like Any Other: Dimensions of Conflict in the European Parliament', paper presented at the second Annual Meeting of the European Consortium for Political Research, Marburg, 18-21 September.

Hoffmann, S. (1966) 'Obstinate or obsolete? The fate of the nation-state and the case of Western Europe', Daedalus, 95 (3), 862-914. 
Holzinger, Katharina (1997) 'The influence of the new members on EU environmental policy-making. A game-theoretical approach', in Michael Skou Andersen and Duncan Liefferink (eds), The Innovation of European Environmental Policy. Copenhagen: Scandinavian University Press, 59-82.

Hooghe, L. (1999) 'Supranational Activists or Intergovernmental Agents? Explaining the Orientations of Senior Commission Officials Toward European Integration', Comparative Political Studies, 32 (4), 435-63.

Hooghe, L. and Marks, G. (1999) 'The Making of a Polity: The Struggle over European Integration' in H. Kitschelt, P. Lange, G. Marks and J. D. Stephens (eds), Continuity and Change in Contemporary Capitalism. Cambridge: Cambridge University Press, pp. 70-97.

Hooghe, L., Marks, G. and Wilson, C. J. (2002) 'Does Left/Right Structure Party Positions on European Integration?', Comparative Political Studies, 35 (8), 965-89.

Hooghe, L., Marks, G. and Wilson, C. J. (2004) 'Does Left/Right Structure Party Positions on European Integration?', in G. Marks and M. R. Steenbergen (eds), European Integration and Political Conflict. Cambridge: Cambridge University Press, pp. 120-40.

Hosli, M. O. (1996) 'Coalitions and Power: Effects of Qualified Majority Voting in the Council of the European Union', Journal of Common Market Studies, 34 (2), 255-73.

Hug, S. and König, T. (2002) 'In View of Ratification: Governmental Preferences and Domestic Constraints at the Amsterdam Intergovernmental Conference', International Organization, 56 (2), 447-76.

Hughes, J., Sasse, G. and Gordon, C. (2002) 'Saying "Maybe" to the "Return to Europe". Elites and the Political Space for Euroscepticism in Central and Eastern Europe', European Union Politics, 3 (3), 327-55.

Kerremans, B. (1998) 'The Political and Institutional Consequences of Widening: Capacity and Control in an Enlarged Council' in P.-H. Laurent and M. Maresceau (eds), The State of the European Union. Volume 4. Deepening and Widening. Boulder CO: Lynne Rienner, pp. 87-109.

Kim, J.-O. and Mueller, C. W. (1978) Factor Analysis. Statistical Methods and Practical Issues. London: Sage.

König, T. and Hug, S. (2000) 'Ratifying Maastricht. Parliamentary Votes on International Treaties and Theoretical Solution Concepts', European Union Politics, 1 (1), 93-124.

Kreppel, A. and Tsebelis, G. (1999) 'Coalition Formation in the European Parliament', Comparative Political Studies, 32 (8), 933-66.

Kreppel, A. (2002) The European Parliament and Supranational Party System. Cambridge: Cambridge University Press.

Lane, J.-E. and Mattila, M. (1998) 'Der Abstimmungsprozess im Ministerrat' in T. König, E. Rieger, H. Schmitt (eds), Europa der Bürger? Voraussetzungen, Alternativen, Konsequenzen. Frankfurt: Campus, pp. $328-43$.

Lipset, S. M. and Rokkan, S. (1967) 'Cleavage Structures, Party Systems, and Voter Alignments: An Introduction' in S. M. Lipset and S. Rokkan (eds), Party Systems and Voter Alignments. New York: Free Press, pp. 1-64.

Majone, G. (1996) Regulating Europe. London: Routledge.

Marks, G. and Steenbergen, M. R. (2002) 'Understanding Political Contestation in the European Union', Comparative Political Studies, 35 (8), 879-92.

Marks, G. and Steenbergen, M. R. (2004) European Integration and Political Conflict. Cambridge: Cambridge University Press.

Marks, G. and Wilson, C. J. (2000) 'The Past in the Present: A Cleavage Theory of Party Response to European Integration', British Journal of Political Science, 30 (3), 433-59.

Mattila, M. (2004) 'Contested Decisions. Empirical Analysis of Voting in the EU Council of Ministers', European Journal of Political Research, 43 (1), 29-50.

Mattila, M. and Lane, J.-E. (2001) 'Why Unanimity in the Council? A Roll Call Analysis of Council Voting', European Union Politics, 2 (1), 31-52.

Moravcsik, A. (1998) The Choice for Europe: Social purpose and state power from Messina to Maastricht. Ithaca NY: Cornell University Press.

Noury, A. G. (2002) 'Ideology, Nationality and Euro-Parliamentarians', European Union Politics, 3 (1), 33-58.

Noury, A. G. and Roland, G. (2002) 'More power to the European Parliament?', Economic Policy, 35, 280-319.

Nugent, N. (1999) The Government and Politics of the European Union. London: Macmillan. 
Page, E. (1997) People Who Run Europe. Oxford: Clarendon.

Pennings, P. (2002) 'The Dimensionality of the EU Political Space. The European Elections of 1999', European Union Politics, 3 (1), 59-80.

Peters, G. and Wright, V. (2001) 'The national co-ordination of European policy-making: negotiating the quagmire', in J. Richardson (ed.), European Union. Power and policy-making. London: Routledge, pp. 155-78.

Ray, L. (1999) 'Measuring party orientations towards European integration: Results from an expert survey', European Journal of Political Research, 36 (2), 283-306.

Rodden, J. (2002) 'Strength in Numbers? Representation and Redistribution in the European Union', European Union Politics, 3 (2), 151-75.

Scharpf, F. W. (1994) 'Autonomieschonend und gemeinschaftsverträglich: Zur Logik einer europäischen Mehrebenenpolitik', in F. W. Scharpf, Optionen des Föderalismus in Deutschland und Europa. Frankfurt/Main: Campus, pp. 131-55.

Schnell, R., Hill, P. B. and Esser, E. (1999) Methoden der empirischen Sozialforschung. München: Oldenbourg.

Schofield, N., Miller, G. and Martin, A. (2003) 'Critical Elections and Political Realignments in the USA: 1860-2000', Political Studies, 51 (2), 217-40.

Sedelmeier, U. (2002) 'Sectoral Dynamics of EU enlargement: advocacy, access and alliances in a composite policy', Journal of European Public Policy, 9 (4), 626-49.

Selck, T. (2004) 'On the Dimensionality of European Union Legislative Decision-Making', Journal of Theoretical Politics, 16 (2), 203-23.

Selck, T. and Steunenberg, B. (2004) 'Between power and luck: The European Parliament in the EU Legislative Process', European Union Politics, 5 (1), 25-46.

Smith, A. D. (1991) Nations and nationalism. London: Penguin.

Streeck, W. and Schmitter, P. C. (1996) 'Gemeinschaft, Markt, Staat - und Verbände? Der mögliche Beitrag von privaten Interessenregierungen zu sozialer Ordnung' in P. Kenis, V. Schneider (eds), Organisation und Netzwerk. Institutionelle Steuerung in Wirtschaft und Politik. Frankfurt/Main: Campus, pp. 123-64.

Thomson, R., Boerefijn, J. and Stokman, F. (2004) 'Actor Alignments in European Union Decision Making', European Journal of Political Research, 43 (2), 237-61.

Thomson, R., Stokman, F., Achen, C. and König, T. (forthcoming) The European Union Decides. Unpublished Book Manuscript.

Tsebelis, George (1994) 'The Power of the European Parliament as a Conditional Agenda Setter', American Political Science Review, 88 (1), 128-42.

Tsebelis, G. and Garrett, G. (1996) 'An Institutional Critique of Intergovernmentalism', International Organization, 50 (2), 269-99.

Young, A. and Wallace, H. (2000) Regulatory Politics in the Enlarging European Union. Manchester: Manchester University Press. 